\title{
The Correlation Between the Criminal Sentence Period and the Intention of Prisoners to Stop Using Drugs in Class I Correctional Facility of Bandar Lampung
}

\author{
Aditia Arief Firmanto ${ }^{1}$, Prida Harkina ${ }^{2}$, Vira Sandayanti ${ }^{3}$ \\ ${ }^{1}$ Faculty of Law, Universitas Malahayati, Indonesia \\ aditia.malahayati@gmail.com \\ 2 Faculty of Medical Sciences, Universitas Malahayati, Indonesia, \\ prida@malahayati.ac.id \\ 3 Faculty of Medical Sciences, Universitas Malahayati, Indonesia, \\ virasanda@malahayati.ac.id
}

\begin{abstract}
Introduction to the Problem: The length of the criminal sencenting can create an intention in prisoners to stop using drugs. Psychologically, the intention is seen from how strong a person's desire to display behavior and how much effort is planned or will be made to display behavior.

Objective: This study intends to determine the relationship between the length of the sentence and the intention to stop using drugs in Class I prisons of Bandar Lampung. The variables in this study were the length of the sentence and the intention to stop using drugs. The research samples in this study were the drug convicts in Class I Correctional Facility of Bandar Lampung,

Methodology: Data collection method uses quantitative and combines with the qualitative method. The data analysis method of descriptive quantitative uses Linkert Scale approach accumulated with the Pearson Product Moment correlation technique by using the Statistical Packages for Social Sciences 20 application program. Data analysis method of qualitative descriptive uses empirical normative approach.

Findings: The result in this study is that there is no relationship between the length of the sentence and the intention to stop using drugs in the Class I Correctional Facility in Bandar Lampung. Based on the correlation test results, the $r$ value was -0.088 with significance $=0.381$ where $(p>0.05)$. The data shows the relationship between the length of the sentence and the intention to stop using drugs in the Class I Correctional Facility in Bandar Lampung is not proven. It means that there are other aspects that more influencing the intention of drug use. Additionally, the effectiveness of imprisonment for drug users in the Class I prison in Bandar Lampung has not run optimally, namely supporting facilities and facilities such as overcapacity for prisoners and prisoners.
\end{abstract}

Paper Type: Research Article

Keywords: Criminal Sentence Length; Intention; Drugs; Prisoners 


\section{Introduction}

As the third most populous city on the island of Sumatra, Bandar Lampung has a serious problem with the high number of drug abuse cases. Additionally, as being a transit area, according to the National Narcotics Agency of Lampung Province, which entered the red zone for drugs in 2019. Based on data input from the National Narcotics Agency of Lampung Province, five regencies in Lampung Province included in the red zone are Bandar Lampung City, Way Kanan Regency, Mesuji, East Lampung, and South Lampung. According to Hendry Budiman, the Head of the Eradication Division of the National Narcotics Agency of Lampung (Badan Narkotika Nasional Provinsi, hereinafter referred to as BNNP Lampung), the comparison of data on areas that were highlighted by the BNNP Lampung in Lampung Province in 2018 and 2019 tend to be similar. The vulnerability of the area in question is allegedly correlated with the involvement of inmates (prisoners) in Correctional Institutions and detention centers in each region (Hasan \& Firmansyah, 2020).

Based on the data from the Correctional Database System of the Directorate General of Corrections, all ranks and drug convicts in Lampung as of December 2015 are 1275 and can be concluded to reach $40 \%$ of the prison capacity. In other words, the number of drug cases has exceeded the capacity in Bandar Lampung (Firmanto, 2019). Based on the survey conducted, the status of detainees is divided into two, drug dealers and drug users. The number of drug dealers reached 475 people, with the highest number in Kalianda Class II Prison (140 people), then Bandar Lampung Class I Prison (100 people). Meanwhile, the number of prisoners and detainees with the highest drug user status is found in Class IIA Kalianda Prison with 195 people, Class IIA Narcotics Prison Bandar Lampung with 115 people, and Class I Prison Bandar Lampung with 100 people (Triyanto \& Triyanto, 2020).

The previous research, involving an interview with the National Narcotics Agency with one of the counselors at one of the Ghrasia Mental Hospitals, shows that $70 \%$ of drug addicts who undergo rehabilitation at the Ghrasia Mental Hospital experience a relapse or return to taking drugs after the rehabilitation program ends. It can be seen from the experience of those who have undergone 3 or 4 times of rehabilitation. There are even addicts who have been out of rehabilitation up to 10 times. Usually, addicts who experience relapse are caused by a bad mood, low self-efficacy, pressure from the environment (stressor), and the patient's environment is still surrounded by drug users. Counselors say that patients who are still in an intense relationship with other users will be easily triggered and cause the desire to retake the drug. Drug users will feel several things due to the time-lapse, one of which is to return to using drugs in large quantities as an act of revenge for the longing to use drugs. This, if left unchecked, can cause overdose (OD) and even death for users who relapse (Jainah, 2020).

In addition to rehabilitation, there is a final alternative, the criminal proceedings. The main problem in criminal law concerns 3 (three) things: the criminal acts, the criminal 


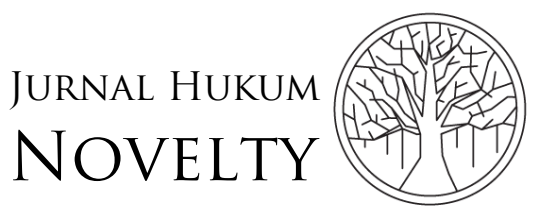

Volume 12, Issue 02, 2021, pp. 248-266

P-ISSN: $1412-6834$

E-ISSN: 2550-0090

responsibility, and crime and punishment. In connection with the three main legal issues above, the science of criminal law developed is more about dogmatic problems of criminal law than criminal law. There has not been much discussion about criminal sanctions that strengthen criminal law, the discussion of the entire content of criminal law is still unfinished (Hidayatun \& Widowaty, 2020). In the sociological level and in the practice of criminal law enforcement, the term "punishment" (hukuman) is also often used for the term "criminal sentence" (pemidanaan). However, considering that the term "punishment" is broader than the scope of "criminal sentence", this study will use the term "criminal sentence period" instead of "punishment period" (Firmanto, 2017).

Based on the combined theory, the sentencing aims not only to provide suffering and a deterrent effect to perpetrators of criminal acts but also as a "medicine" for criminals. Thus, they can reflect on all their mistakes so that they do not repeat their actions in the future. Likewise, in the case of drug convicts, especially drug users, the period of criminal sentence is expected to foster an intention or desire to stop using drugs (Asyharudddin et al., 2020).

Psychologically, intention reflects on how strong a person's desire to display behaviour and how much effort is planned or made to display a behaviour (Ajzen, 1991). According to Ajzen, intention refers to the individual's possibility to displayor not display certain behaviours, which is influenced by three factors. The first factor is "Attitude towards a Behaviour", i.e. the degree to which a person has a favourable or unfavourable evaluation; or an assessment of the behaviour you want to display (Ajzen, 1991). The second factor is "Subjective Norms", individual perceptions of applicable norms and individual perceptions of social pressures that expect individuals to display or not display a behaviour (Ajzen, 1991). The third factor is "Perception of Behavioural Control," which is how the individual's perception of how easy or difficult it is to display or stop displaying a certain behaviour is a reflection of past experiences as well as anticipated obstacles (Ajzen, 1991). These three factors collaborate in determining how the intention/degree of a person's desire to display/not display a certain behaviour, one of which is the behaviour of stopping drug use by users who have been sentenced in a certain period.

Based on the above descriptions, this article is expected to answer two questions. First is whether there is a relationship between the length of the sentence and the intention to stop using drugs in the Class I Correctional Facility of Bandar Lampung. Secondly, how is the effectiveness of imprisonment for drug users in the Class I Correctional Facility of Bandar Lampung.

\section{Methodology}

This study applies a quantitative approach, which is a research approach that produces research data in the form of numbers and is then analyzed with statistics. The research design used cross-sectional research to study the dynamics of the 
correlation of risk factors with consequential factors. The research subject is $100 \mathrm{drug}$ convicts in the Class I Correctional Facility of Bandar Lampung (Sugiyono, 2011). The inmate is asked to sign an informed consent form. This research approach is empirical normative research, which departs from the correlation of the length of sentencing for drug users regulated by the Narcotics Law and the intention of stopping drug use in inmates in Class I Prison of Bandar Lampung. The measuring tool is a questionnaire which later be analysed and processed using the Linkert Scale, Pearson Product Moment Correlation Technique, and the Statistical Packages for Social Sciences (SPSS 20) Application Program. The research results are expected to be the input and reference for the revision of the Narcotics Law.

\section{Sampling Method}

Samples were taken by using the total sampling technique. The populations in this study were all drug convicts totaling 100 people. Total sampling is a sampling technique where the number of samples is the same as the population. The reason for taking total sampling is because, according to Sugiyono (Sugiyono, 2011), the total population of 100 of the entire population is used as a research sample.

\section{Sample Characteristics}

The characteristics of the sample in this study were drug convicts in the Class I prisons in Bandar Lampung: the relationship between the length of sentence period and the intention to stop using drugs of the prisoners in Class I Correctional Facility of Bandar Lampung

\section{Research procedure}

\section{Research Instruments}

1. Variable of the length of the sentence in this study is obtained by using the time the judge has determined in the verdict on each convicted subject.

2. Variable Intention, the measuring instrument used is the Intention to Stop Using Drugs in the form of a Likert scale of 30 items using four alternative answers, namely: strongly agree (SA), agree (A), disagree (D), and strongly disagree (SD). Some statements are favourable in nature, and some are unfavourable. For favourable items, subject scores start from 4,3,2,1. Meanwhile, for unfavourable items, subject scores start from 1,2,3,4 (Azwar, 2003).

3. Validity and Reliability

a. Validity

Validity testing is intended to determine that the measuring instrument is able to produce accurate data in accordance with the measurement objectives. The validity in this research is content validity. Validity is estimated through testing the test content with rational analysis or through professional judgment (Azwar, 2003).

b. Reliability

Reliability estimation in this study uses an internal consistency approach intended to avoid problems usually caused by the retest approach and the 
parallel approach (Azwar, 2003). The reliability test in this study use the Alpha Combrach formula(Azwar, 2003).

\section{Research Preparation}

Before carrying out data collection, the researchers submitted a notification of research permission and applied for a letter of assignment to the Dean of the Faculty of Law, Malahayati University, for research at the Class I prison in Bandar Lampung. After that, the Dean of the Faculty of Law made a research notification letter to the University Research and Community Service Institute (Lembaga Penelitian dan Pengabdian Masyarakat, hereinafter referred to as LPPM). After that, the LPPM of Malahayati University made an application for a research permit to the National Unity and Politics of the Ministry of Home Affairs (Kesatuan Bangsa dan Politik Kementrian Dalam Negeri) which changed to the Lampung Province Investment Office and OneStop Integrated Service. Then, the research permit recommendation letter was issued by the relevant agency and the researcher submitted an application for a research permit to the Ministry of Law and Human Rights Lampung Regional Office with an attachment of the recommendation letter from the Lampung Province Investment and One Stop Service Office. Furthermore, the next step is processing ethics worthy to the Ethics Committee at Malahayati University, Lampung. Preparations made by the author in this study include the preparation of measuring instruments. Documents submitted to the Ethics Committee are complete, including ethical protocols and measuring instruments to be used.

\section{Validity and Reliability Test}

1. Test the validity of the intention to stop using drugs

Test the validity of the intention to stop using drugs uses the Pearson Product Moment correlation technique. This validity test was carried out using a computer tool using the Statistical Packages for Social Sciences (SPSS) Application program. According to (Azwar, 2003), if the number of items with a discriminatory power index equal to or greater than 0.30 exceeds the number of items planned to be used as a scale, the researcher can choose the highest discriminatory items power index. Based on the results of the validity test of the intention measuring instrument, 28 valid items have a corrected item-total correlation score that moves from 0.328 to 0.750 . Furthermore, 12 items fall out of 40 items, namely items number 1, 3, 10, 22, 23, 24, $25,30,33,35,37$ and 38.

\section{Emotional Intelligence Reliability Test}

Based on the reliability test results using the Cronbach alpha formula, a score of 0.852 was obtained. It can be said that the scale is declared reliable. According to Azwar (Azwar, 2003) the scale reliability coefficient of less than 0.6 is considered unfavourable. The reliability coefficient of 0.7 is acceptable, while above 0.8 is good. The results of the reliability test can be seen in Table 5.1 below: 
Table 1. Reliability Statistics

\begin{tabular}{cc}
\hline Cronbach's Alpha & N of Items \\
\hline 0,852 & 40 \\
\hline
\end{tabular}

\section{Assumption Test Results}

Before testing the hypothesis, there shall be assumption test. The assumption test or prerequisite test must be carried out on the sample to determine whether the distribution is normal or not. The scale assumption test is carried out using the SPSS application. The assumption test consists of a distribution normality test to see the distribution of $X$ and $Y$ variables is normal or not, and a linearity test is to see whether the relationship between $\mathrm{X}$ and $\mathrm{Y}$ variables is linear as a condition for testing the value of $r$ (Hadi, 2015a).

\section{Test for Normality of the Distribution of Emotional Intelligence}

The distribution normality test was carried out to determine whether the data population was normally distributed or not, and the data was declared normally distributed if the significance was greater than 0.05 (Hadi, 2015b). The normality test was carried out using the One-Sample Kolmogorov-Smirnov Test in the SPSS application. The normality of each scale can be seen from the magnitude of the Kolmogorov-Smirnov. coefficient.

Tabel 2. Tests of Normality

\begin{tabular}{ccccccc}
\hline & \multicolumn{3}{c}{ Kolmogorov-Smirnova $^{\text {a }}$} & \multicolumn{3}{c}{ Shapiro-Wilk } \\
\cline { 2 - 7 } & Statistic & Df & Sig. & Statistic & Df & Sig. \\
\hline Intensi & .112 & 100 & $.003^{*}$ & .905 & 100 & .000
\end{tabular}

* This is a lower bound of the true significance.

a: Lilliefors Significance Correction

Based on the results of the analysis carried out using the SPSS application, the intention to stop using drugs was proven to have an abnormal distribution, as evidenced by the Kolmogorof-Smirnov coefficient value of 0.03 .

\section{Test the Normality of the Distribution of Sentencing Periods}

The distribution normality test was carried out to determine whether the data population was normally distributed or not, and the data was declared normally distributed if the significance was greater than 0.05 (Hadi, 2015b). The normality test was carried out using the One-Sample Kolmogorof-Smirnov Test in the SPSS application. The normality of each scale can be seen from the magnitude of the Kolmogorof-Smirnov coefficient. 
Tabel 3. Tests of Normality

\begin{tabular}{lcccccc}
\hline & \multicolumn{3}{c}{ Kolmogorov-Smirnova } & \multicolumn{3}{c}{ Shapiro-Wilk } \\
\cline { 2 - 7 } & Statistic & Df & Sig. & Statistic & Df & Sig. \\
\hline Pemidanaan & .222 & 100 & $.000^{*}$ & .804 & 100 & .000 \\
\hline
\end{tabular}

*. This is a lower bound of the true significance.

a. Lilliefors Significance Correction

Based on the analysis carried out using the SPSS application, the time scale of the sentence was proven to have an abnormal distribution as evidenced by the Kolmogorof-Smirnov coefficient value of 0.000 .

\section{Linearity Test}

The linearity test was conducted to determine whether the independent variable and the dependent variable had a linear relationship or not. The linearity test was carried out with Deviation from Linearity in the SPSS application at a significance level of $p>0.05$. The linearity test result on the scale of intention to stop using drugs with the length of the sentence is presented in table 4.

Table 4. ANOVA

\begin{tabular}{|c|c|c|c|c|c|c|c|}
\hline \multirow{6}{*}{$\begin{array}{l}\text { Criminal } \\
\text { Intention }\end{array}$} & & & $\begin{array}{l}\text { Sum of } \\
\text { Squares }\end{array}$ & df & $\begin{array}{c}\text { Mean } \\
\text { Square }\end{array}$ & $\mathbf{F}$ & Sig. \\
\hline & \multirow{3}{*}{$\begin{array}{l}\text { Between } \\
\text { Groups }\end{array}$} & (Combined) & 360.073 & 2 & 180.037 & .960 & .386 \\
\hline & & Linearity & 339.453 & 1 & 339.453 & 1.811 & .182 \\
\hline & & $\begin{array}{l}\text { Deviation } \\
\text { from } \\
\text { Linearity }\end{array}$ & 20.620 & 1 & 20.620 & .110 & .741 \\
\hline & \multicolumn{2}{|c|}{ Within Groups } & 18183.317 & 97 & 187.457 & & \\
\hline & \multicolumn{2}{|l|}{ Total } & 18543.390 & 99 & & & \\
\hline
\end{tabular}

The linearity testing result on the variables showed that there was a linear relationship between the length of the sentence and the intention to stop using drugs $(F=0.110$ and a significance of 0.741 , where $p>0.05$ )

\section{Hypothesis Test}

At this stage, the authors tested the hypothesis using the Spearman Rank Analysis technique because the data distribution was not normally distributed using the Statistical Product and Service Solution (SPSS) software version 20.0. The results (output) were obtained with a value of -0.088 with a significance $=0.381$ where $\mathrm{P}>0.05$ means the hypothesis is not proven. It is possible because other factors can influence the intention to stop using drugs, but not the length of the sentence. It is related to the fact that even though they have been sentenced to a criminal offense and underwent a coaching process at the Class I prison in Bandar Lampung, there are still prisoners who have been imprisoned again for repeating drug use.

\section{Categorization}

Hypothetical score (score based on the hypothesis) 
Minimum score $=40$

Maximum score $=160$

Empirical score (score based on real data in the field)

Minimum score $=70$

Maximum score $=148$

Range $=160-40=120$

Mean $=(160+40) / 2=100$

$\mathrm{SD}=120 / 6=20$

1) Low category $=x<160-20$

$\mathrm{X}=<80$

2) Medium category $=100-(1 \times 20) X-100+(1 \times 20)$

$\mathrm{X}=80-120$

3) High category $=100+(1 \times 20)$

$\mathrm{X}=120$

\section{Frequency}

a. Intention of drug use

Low: 1 person

Medium: 20 people

Height: 79 people

b. Sentencing

Low: 24 people

Medium: 42 people

Height: 34 people

Based on the hypothesis test result, the $r$ value was -0.088 with a significance $=0.381$ where ( $p>0.05)$, means this result shows that there is no relationship between the intention to stop using drugs and the length of the sentence. It means the hypothesis is not proven. The result is possible because there are other factors that can influence the intention to stop using drugs, but not the length of the sentence. It is related to the fact that even though they have been sentenced to a criminal offense and have undergone a coaching process at the Class I prison in Bandar Lampung, there are still prisoners who have been imprisoned again for relapse using drugs. It is supported by the fact that in the field, one of the cases of drug dealers and users on behalf of the perpetrators Riski and Yuda (a recidivist) in October 2019 was re-arrested by the Bandar Lampung Police team, and even Riski has been jailed twice for the same case (Kupas Tuntas, 2019)

Based on the results of this study, the suggestion from the researcher for further research is to examine other factors that may be related to the intention to stop using drugs in prisoners in Class I Lapas Bandar Lampung. 


\section{Results and Discussion}

The punishment of drug users cannot be separated from the criminal system adopted by the legal system in Indonesia. The purpose of the criminal system is essentially the operation of law enforcement carried out by the judicial system based on legal instruments that regulate the criminalization of drug abusers and illicit trafficking, namely Law Number 35 of 2009 concerning Narcotics as a substitute for Law no. 22 of 1997 concerning Narcotics (Hikmawati, 2016). Imprisonment is a crime in the form of deprivation of freedom or freedom of movement from a convict by placing him in a correctional institution (Priyatno, 2009). Imprisonment was officially stipulated in Indonesia since the entry into force of the Criminal Code on January 1, 1918; previously, Indonesia only recognized corporal punishment and fines. At that time, there was no clear boundary to distinguish between corporal punishment and imprisonment. Its implementation was in the form of sorrow intentionally inflicted on someone who violated the criminal law.

The punishment imposed on the perpetrator of a crime is something that is fair in various perspectives of punishment theory (Roy, 2014). However, it must also be considered in terms of justice and the benefits of the form of punishment that will be imposed on the perpetrators of the crime. The sentence shall not violate the human rights of the perpetrators of the crime itself.

Imprisonment that robs a person's right to freedom of course violates human rights, especially if imprisonment is imposed for life; this is a very inhuman form of punishment (Gumboh, 2011). Imprisonment sometimes has to be served by someone who is sentenced to death, which is often not clear when he will be sentenced. It must be admitted that there are many negative things from the coaching system in prison that prisoners must experience, including:

1) Sociologically, imprisonment makes a person separated from his family. If he is the head of the family, he is responsible for his family, wife and children or other people before he is imprisoned, besides that of course the fulfillment of his biological needs will be disrupted;

2) In prisons, the coaching system doesn not go well, in LAPAS, groups were found that often blackmailed other groups, acted violently and fought. LAPAS officers often act favouritism, and LAPAS also functions as a place for the transfer of knowledge of crime so that the adage arises those prisons are schools of crime science (SIK) (Kokong, 2012);

3) The criminal system through imprisonment makes an inmate isolated from the community and family, so that psychologically prisoners can experience stress and decrease mental health (Hasan, 2017);

4) When they leave prison, people are actually afraid and do not even want to accept ex-convicts again because they are afraid that the ex-convicts will commit crimes again. There was the labelling of ex-convicts as criminals. When he left prison, it was very difficult for him to get a job to support himself and his family. Not a few inmates ended up committing crimes again (recidivists). 
The developments in the world today show a strong tendency to change in viewing narcotics users who are no longer seen as criminals but as victims or patients who must be given empathy (Senjaya et al., 2021). The criminal sanctions imposed on narcotics addicts are in the form of serving a sentence in prison, while the sanctions for actions given to narcotics addicts as victims are in the form of treatment and/or care provided in the form of rehabilitation facilities. The implementation system is that the period of treatment and/or treatment is calculated as a period of serving a sentence (Fitri \& Yusran, 2020). Law No. 22 of 1997 and Law No. 35 of 2009 concerning Narcotics has adhered to a double-track system in the formulation of sanctions against criminal acts of narcotics abusers, although it is still freedom for judges to pass verdicts/decisions in handling cases of narcotics users, based on the judge's belief in giving action sanctions. This can be proven by looking at and also understanding the criminal provisions against narcotics abusers as contained in the provisions of Article 85 of Law No. 22 of 1997, namely:

"Whoever without rights and against the law:

a) Using Class I Narcotics for himself, shall be punished with imprisonment for a maximum of 4 (four) years.

b) Using Narcotics Class II for himself, shall be punished with imprisonment for a maximum of 2 (two) years.

c) Using Class III Narcotics for himself, shall be punished with imprisonment for a maximum of 1 (one) year."

The provisions for rehabilitation for narcotics users are regulated in Article 45 and Article 47 of Law No. 22 of 1997. Article 45 regulate that "Drug users are required to undergo treatment and/or treatment". Article 47 regulate that:

a. Judges who examine narcotics addict cases may:

1) Decide to order the person concerned to undergo medication and/or treatment if the narcotic addict is proven guilty of committing a narcotic crime: or

2) Determine to order the person concerned to undergo medication and/or treatment, if the narcotic addict is not proven guilty of committing a narcotic crime.

b. The period of undergoing medication and/or treatment for narcotics addicts as referred to in paragraph (1) letter a, is counted as serving a sentence.

Furthermore, in the latest Narcotics Law, namely Law No. 35 of 2009, the provisions regarding narcotics abuse for oneself are regulated in Article 127, namely:

a. Each abuser of:

1) Narcotics class I for himself shall be sentenced to a maximum imprisonment of 4 (four) years;

2) Narcotics class II for himself shall be sentenced to a maximum imprisonment of 2 (two) years;

3) Narcotics class III for himself shall be sentenced to a maximum imprisonment of 1 (one) year. 
b. In deciding the case as referred to in paragraph (1), the judge is obliged to pay attention to the provisions as referred to in Article 54, Article 55, and Article 103.

c. If the abuser, as regulated in paragraph (1) can be proven or proven to be a victim of a narcotics abuser, the abuser is obliged to undergo medical rehabilitation and social rehabilitation.

Considering the regulation of sentencing above, it can be concluded that the formulation of sanctions against criminal acts of narcotics abuse refers to a double track system with the concept of restorative justice. Based on a victimology review, those narcotics addicts are self-victimizing victims, namely victims as perpetrators. Victimology continues to stipulate narcotics abusers as victims, even though they are victims of crimes they commit themselves (Jamal, 2020).

The settlement of cases with restorative justice aims to produce success in law enforcement by involving all parties involved in a crime, namely perpetrators, victims, family members of perpetrators and victims, and the community. The settlement of criminal cases can be fairer and more effective because all parties are actively involved (Joseph Solomon \& Nwankwoala, 2014). Criminals must repair the consequences of their crimes. Victims physically and psychologically receive compensation in the form of compensation and even reduce fear or trauma. The community takes part in the recovery of negative consequences by accepting the perpetrators back and teaching members other people to not commit other crimes.

After the Narcotics Law has been in effect for more than 12 years, the Supreme Court issued a circular letter to provide guidance to judges, namely Supreme Court Circular Letter No. 04 of 2010 concerning Placement of Abuse, Victims of Abuse, and Narcotics Addicts into Medical Rehabilitation and Social Rehabilitation Institutions, which are revisions of the Supreme Court Circular Letter No. 07 of 2009. Of course, this circular is a step forward in building the paradigm of stopping the criminalization or decriminalization of narcotics addicts (Yuherawan \& Rosdiana, 2020).

In addition, the Bill of Criminal Code, which was drafted on 9 July 2018 (from the Government) provisions for Narcotics Crimes, was prepared differently from the previous draft on 2 February 2018. The 9th July 2018 draft only arranges regarding the aspects of planting, maintaining, possess, store, control, or provide narcotics Category I, possess, store, control, or provide Narcotics Category I, II, III, produce, import, export, or distribute Narcotics Category I, II, III, offer for sale, sell, buy, receive, become intermediaries in buying and selling, exchanging, or delivering Narcotics Category I, II, III, carrying, sending, transporting, or transiting Narcotics Category I, II, III, using against other people or giving Narcotics to be used by others Category I, II, III, (which can be seen in the following table) (Arief Firmanto, 2020). 
Table 5. The Comparison of Narcotics Crime Arrangements in the Narcotics Law and the draft Criminal Code Bills of 9th July 2018 (Napitupulu \& Rahmawati, 2019).

\begin{tabular}{|c|c|c|c|c|}
\hline No. & $\begin{array}{l}\text { Difference } \\
\text { Aspect }\end{array}$ & Narcotics Law & $\begin{array}{l}\text { Draft of Criminal } \\
\text { Code }\end{array}$ & Notes \\
\hline 1. & $\begin{array}{l}\text { Not Against } \\
\text { the law }\end{array}$ & $\begin{array}{l}\text { No rights or against the } \\
\text { law }\end{array}$ & No rights & different \\
\hline 2. & $\begin{array}{l}\text { action } \\
\text { element }\end{array}$ & $\begin{array}{l}\text { Planting, maintaining, } \\
\text { possessing, keeping, } \\
\text { controlling, or providing }\end{array}$ & $\begin{array}{l}\text { Planting, maintaining, } \\
\text { possessing, keeping, } \\
\text { controlling, or } \\
\text { providing }\end{array}$ & Same \\
\hline 3. & $\begin{array}{l}\text { Criminal } \\
\text { Threat }\end{array}$ & $\begin{array}{l}\text { imprisonment with a } \\
\text { minimum of } 4 \text { years and } \\
\text { maximum of } 12 \text { years, } \\
\text { and a fine of minimum } \\
\text { Rp. } 800 \text { million and a } \\
\text { maximum of Rp. } 8 \text { billion }\end{array}$ & $\begin{array}{l}\text { Imprisonment Min. } 4 \\
\text { years Max. } 12 \text { years } \\
\text { and a fine of } \\
\text { minimum IDR } 150 \\
\text { million maximum } \\
\text { IDR } 2 \text { billion }\end{array}$ & $\begin{array}{l}\text { Different } \\
\text { fines }\end{array}$ \\
\hline 4. & $\begin{array}{l}\text { Aggravation } \\
\text { of } \\
\text { punishment }\end{array}$ & $\begin{array}{l}\text { Exceeding } 1 \text { kilogram or } \\
\text { exceeding } 5 \text { tree trunks }\end{array}$ & $\begin{array}{l}\text { Exceeding } 1 \text { (one) } \\
\text { kilogram or } \\
\text { exceeding } 5 \text { (five) } \\
\text { tree trunks }\end{array}$ & Same \\
\hline 5. & $\begin{array}{l}\text { Aggravation } \\
\text { of } \\
\text { punishment } \\
\text { threat }\end{array}$ & $\begin{array}{l}\text { Life imprisonment or } \\
\text { imprisonment minimum } \\
\text { of } 5 \text { (five) years and } \\
\text { maximum } 20 \text { (twenty) } \\
\text { years and criminal } \\
\text { vengeance, }+1 / 3\end{array}$ & $\begin{array}{l}\text { Life imprisonment or } \\
\text { imprisonment min. } 5 \\
\text { (five) max. } 20 \\
\text { (twenty) years and a } \\
\text { revenge sentence IDR } \\
2 \text { billion maximum } \\
\text { IDR } 15 \text { billion }\end{array}$ & $\begin{array}{l}\text { Different } \\
\text { fines }\end{array}$ \\
\hline
\end{tabular}

Table 6. Possessing, Keeping, Controlling, or Providing

\begin{tabular}{lllll}
\hline No. & $\begin{array}{l}\text { Difference } \\
\text { Aspect }\end{array}$ & Narcotics Law & $\begin{array}{l}\text { Draft of Criminal } \\
\text { Code }\end{array}$ & Notes \\
\hline 1. & $\begin{array}{l}\text { Not Against } \\
\text { the law }\end{array}$ & No rights or against the law & No rights & different \\
\hline 2. & $\begin{array}{l}\text { Action } \\
\text { element }\end{array}$ & $\begin{array}{l}\text { Possess, keep, control, or } \\
\text { provide }\end{array}$ & $\begin{array}{l}\text { possess, keep, } \\
\text { control, or provide }\end{array}$ & same \\
\hline 3. & $\begin{array}{l}\text { Criminal } \\
\text { threat }\end{array}$ & $\begin{array}{l}\text { Imprisonment with a } \\
\text { minimum of 4 years and } \\
\text { maximum of 12 years, and }\end{array}$ & $\begin{array}{l}\text { Minimum } \\
\text { imprisonment of 4 }\end{array}$ & $\begin{array}{l}\text { Different } \\
\text { fines }\end{array}$ \\
& & $\begin{array}{l}\text { a fine of a minimum of IDR a } \\
\text { maximum of 12 }\end{array}$ & \\
& & 800 million max. IDR 8 & years, and a fine of \\
billion & min. IDR 150 million & \\
\hline
\end{tabular}


max. IDR 2 billion

(Group I)

\begin{tabular}{|c|c|c|c|c|}
\hline 4. & Aggravation & More than 5 grams & More than 5 grams & same \\
\hline 5. & $\begin{array}{l}\text { Aggravation } \\
\text { of } \\
\text { punishment } \\
\text { threat }\end{array}$ & $\begin{array}{l}\text { Life imprisonment or } \\
\text { imprisonment min. } 5 \text { (five) } \\
\text { max. } 20 \text { (twenty) years and } \\
\text { a maximum fine of }+1 / 3 \text {. }\end{array}$ & $\begin{array}{l}\text { Life imprisonment } \\
\text { or imprisonment } \\
\text { min. } 5 \text { (five) max. } 20 \\
\text { (twenty) years and a } \\
\text { revenge sentence. } \\
\text { IDR } 500 \text { million } \\
\text { max. IDR } 15 \text { billion }\end{array}$ & $\begin{array}{l}\text { Different } \\
\text { fines }\end{array}$ \\
\hline
\end{tabular}

Tabel 7. Abusers/Users

\begin{tabular}{lllll}
\hline No. & $\begin{array}{l}\text { Difeerence } \\
\text { Aspects }\end{array}$ & Narcotics law & $\begin{array}{l}\text { Draft of Criminal } \\
\text { Code 9 July 2018 }\end{array}$ & Notes \\
\hline 1. & $\begin{array}{l}\text { Person } \\
\text { element }\end{array}$ & $\begin{array}{l}\text { Every abuser for } \\
\text { himself }\end{array}$ & Unregulated & Different \\
\hline 2. & $\begin{array}{l}\text { Criminal } \\
\text { threat }\end{array}$ & $\begin{array}{l}\text { Max. 4 years (Gol. I) } \\
\text { max. 2 years (Gol. }\end{array}$ & Unregulated & Different \\
& & II) max. 1 year (Gol. & & \\
& & III) & Different \\
\hline 3. & Rehabilitation & It is mandatory for & Unregulated & \\
& guarantee & judges to consider & & \\
& & $\begin{array}{l}\text { mandatory } \\
\text { rehabilitation for } \\
\text { victims of abuse }\end{array}$ & & \\
& &
\end{tabular}

The settings described above then do not become a solution. The regulation does not contain the administrative aspects regulated in the Narcotics Law. For example, regarding the classification of narcotics, if it again refers to the administrative law, what is the urgency to include provisions for criminal acts in the Criminal Code Draft. Second, when viewed from the table above, basically, the formulation of the article is the same; the only difference is that it relates to the threat of imprisonment and fines in several articles. It will even lead to duplication, which impacts buying and selling articles and confusion for law enforcement officers to use the articles in the Law or the Criminal Code Draft. The transitional provisions contained in the Criminal Code Draft draft 9 July 2018 are not a solution either.

Article 673

As this Law comes into force, the provisions in the Chapter on Special Crimes in this Law are implemented by law enforcement agencies based on the duties and authorities stipulated in the respective Laws. 


\section{Explanation:}

What is meant by "implemented by law enforcement agencies" in this provision, for example, an institution that organizes the eradication of narcotic crime, in addition to handling narcotics crimes as regulated in the Law on narcotics, also handles narcotics crimes as regulated in this Law. Likewise, the institution that carries out the eradication of corruption and handling corruption crimes as regulated in the Law concerning the eradication of corruption also handles corruption crimes as regulated in this Law.

\section{Article 673A}

1) At the time this Law comes into force, the provisions of the Law which have been partly included in the Chapter on Special Crimes, remain valid and can be applied for a maximum of 5 (five) years by institutions implementing law enforcement.

2) Within a maximum period of 5 (five) years, the Law as referred to in paragraph (1) must have been adjusted to this Law.

Article 673A paragraph (2) explains the necessity of the previous stipulating law to adjust to the Criminal Code Draft, it is not clear what is meant by adjusting because the Criminal Code Draft is a law that generally regulates criminal provisions, whether what is meant by the Narcotics Law must conform to general criminal provisions, or only related to the formulation of the crime. It clearly indicates the ambiguity of the "core crimes" concept proposed by the government and the DPR.

Regarding the criminalization of narcotics users, Law No. 35 of 2009 concerning Narcotics governs about rehabilitation. It is regulated in article 54, which reads, "narcotics addicts and victims of narcotics abuse are obliged to undergo mediation rehabilitation and social rehabilitation." In Law no. 35 of 2009 concerning Narcotics, the agency authorized to carry out the rehabilitation process is the National Narcotics Agency which has been regulated in articles 70 to 72 , has the following duties and authorities:

Article 70

The National Narcotics Agency has the following duties:

1. Formulate and implement national policies regarding the prevention and eradication of narcotics abuse and illicit trafficking;

2. Prevent and eradicate abuse and illicit traffickers of Narcotics and Narcotics precursors;

3. Coordinate with the head of the State Police of the Republic of Indonesia in preventing and eradicating the abuse and illicit trafficking of narcotics;

4. Improve the capacity of medical rehabilitation and social rehabilitation institutions for narcotics addicts, both organized by the government and the community.

5. Empowering the community in the context of preventing, abusing, and illicit trafficking of narcotics and narcotic precursors; 
6. Monitor, direct, and improve community activities in preventing the abuse and distribution of narcotics and narcotics precursors;

7. Carry out bilateral and multilateral cooperation both regionally and internationally, in order to prevent and eradicate illicit trafficking of narcotics and narcotics precursors;

8. Develop a narcotics laboratory and narcotic precursors;

9. Carry out administrative investigations and investigations of cases of abuse and illicit trafficking of narcotics and narcotics precursors;

10. Make a prisoner report regarding the implementation of duties and authorities;

Article 71

In carrying out the task of eradicating and abusing and illicit narcotics and narcotics precursors, the National Narcotics Agency (Badan Narkotika Nasional, hereinafter referred to as "BNN") has the authority to conduct investigations and investigations into the abuse and illicit traffic of narcotics and narcotics precursors.

\section{Article 72}

BNN has the authority to:

1. The authority, as referred to in article 71 , is carried out by BNN investigators

2. BNN investigators, as referred to in paragraph (1), are appointed and dismissed by the head of BNN

3. Further provisions regarding the terms and procedures for the appointment and dismissal of BNN investigators as referred to in paragraph (2) shall be regulated by the regulation of the head of BNN.

An appointed judge will try the examination and arrest of victims and perpetrators of narcotics abuse carried out by BNN. The duties and authorities of this judge have been stated in Article 103 of Law No. 35 of 2009 concerning Narcotics as follows:

"A judge who examines a narcotics addict case may: Decide to order the person concerned to undergo treatment and or treatment through rehabilitation if the narcotic addict is found guilty of committing a narcotic crime or:

a. To stipulate to order the person concerned to undergo treatment and/or treatment through rehabilitation if the narcotic addict is not proven guilty through a narcotic crime.

b. The period of undergoing treatment and/or treatment for narcotics addicts as referred to in paragraph (1) letter a, is calculated as the period of serving a sentence."

From the above, efforts and policies to make good criminal regulations cannot be separated from the purpose of crime prevention. Based on interview data with the Head of Bandar Lampung Class I Prison Registration Ahmad Walid, SH, the total detainees and prisoners amounted to 948 people. In comparison, the capacity of Bandar Lampung Class I Prisons could only accommodate 620 people, resulting in an overcapacity of 53 people, including drug users. 100 people. It impacts supervision that is not optimal by prison security officers because the number of security officers 
is not ideal with the number of inmates, so it is easy for violations committed by inmates. The health of the inmates is not guaranteed because the number of inmates is greater than the prison's capacity, which allows friction and fights between inmates to occur.

Regarding the effectiveness of punishment, it is not limited only to the weight of the Judge's Verdict or the length of the sentence but also relies heavily on supporting facilities. The study results show that the existence and essence of the purpose of a correctional institution, for example, in Class I prisons in Bandar Lampung, is different from a narcotics correctional institution in particular. In addition to restoring the balance of the criminals' attitude so that they are deterrent and do not repeat the crimes, the Class I Prison in Bandar Lampung has an important task to deal with and try to eliminate the nature of drug dependence from its inmates.

\section{Conclusions}

Based on the hypothesis test results, the $r$ value was -0.088 with a significance $=0.381$ where ( $p>0.05)$. This result shows no relationship between the intention to stop using drugs and the length of the sentence. It means the hypothesis is not proven. It is possible because there might be other factors influencing the intention to stop using drugs, but not the length of the sentence. It is related to the fact that even though they have been sentenced to a criminal offense and have undergone a coaching process at the Class I Prison in Bandar Lampung, there are still prisoners who have been imprisoned again for relapse using drugs. In fact, one of the cases of drug dealers and users on behalf of the perpetrators Riski and Yuda (a recidivist) in October 2019 was re-arrested by the Bandar Lampung Police team, and even Riski has been jailed twice for the same case. In addition, the effectiveness of imprisonment for drug users in the Class I Correctional Facility of Bandar Lampung has not run optimally related to the supporting facilities such as overcapacity for detainees and inmates. Prison security officers' supervision is not optimal because the number of security officers is not ideal with the number of inmates, so it is easy for violations committed by the inmates.

From the problems described, based on the results of this study, suggestions from researchers for further research are to examine other factors that may be related to the intention to stop using drugs in prisoners in the Class I Correctional Facility of Bandar Lampung. In addition, the punishment imposed on the perpetrator of the crime must at the same time improve the condition of the victim, the victim's family and restore the condition of the community in accordance with the concept development of punishment towards restorative justice. So, it is necessary to immediately revise the Narcotics Law to ensure legal certainty, justice, and benefit for the perpetrators. In addition, it is necessary to increase the capacity of prisons from the government so that crime prevention efforts for inmates who use drugs in the Class I Correctional Facility of Bandar Lampung can run effectively and maximally. 


\section{Acknowledgment}

The authors would like to thank Universitas Malahayati for the resources provided to conduct this research. Sincere gratitude also goes to anonymous reviewers and editors who have provided constructive feedback so that this manuscript looks worth reading and citing.

\section{Declarations}

Author contribution : Author 1: initiated the research ideas, instrument construction, data collection, analysis, and draft writing; Author 2: revised the research ideas, literature review, data presentation and analysis, and the final draft; Author 3: revised the literature review, analysis, and the final draft and also revised some references.

Funding statement $\quad$ : This research is self-funding research.

Conflict of interest $\quad$ : The authors declare no conflict of interest.

Additional information : No additional information is available for this paper.

\section{References}

Ajzen, I. (1991). The Theory of Planned Behavior. Organizational Behavior and Human Decision Processes, 50(2), 179-211. https://doi.org/10.1016/07495978(91)90020-T

Arief Firmanto, A. (2020). Narcotics Abuse by College Students in Bandar Lampung In Criminology Perspectives. IOSR Journal Of Humanities And Social Science (IOSRJHSS, 25, 28-34. https://doi.org/10.9790/0837-2506082834

Asyharudddin, M., Badaru, B., \& Hidjaz, M. K. (2020). Analisis Sanksi Pidana Terhadap Pelaku Tindak Pidana Narkotika. Pleno Jure, 9(1), 58-71. https://doi.org/10.37541/PLENOJURE.V9I1.390

Azwar, S. (2003). Penyusunan Skala Psikologi (1st ed.). Pustaka Pelajar.

Firmanto, A. A. (2017). Kedudukan Pidana Kebiri dalam Sistem Pemidanaan di Indonesia (Pasca Dikeluarkannya PERPPU No. 1 Tahun 2016). Jurnal Hukum Novelty, 8(1), 1-19. https://doi.org/10.26555/NOVELTY.V8I1.A5523

Firmanto, A. A. (2019). Pembaharuan Hukum Pidana menurut RKUHP Tahun 2018 terhadap Pelaku Penyalahgunaan Narkotika dengan Sistem Rehabilitasi. Keadilan Progresif, 10(2). http://jurnal.ubl.ac.id/index.php/KP/article/view/1353

Fitri, S., \& Yusran, R. (2020). Implementasi Kebijakan Rehabilitasi Pengguna Narkoba pada Badan Narkotika Nasional Provinsi Sumatera Barat. Journal of Civic Education, 3(3), 231-242. https://doi.org/10.24036/JCE.V3I3.400

Gumboh, E. (2011). The Penalty of Life Imprisonment under International Criminal Law. African Human Rights Law Journal, 11(1). https://journals.co.za/doi/abs/10.10520/EJC51939

Hadi, S. (2015a). Metodologi Research untuk Penulisan Paper, Skripsi, Thesis dan Disertasi (1st ed.). Andi Offset.

Hadi, S. (2015b). Statistika (1st ed.). Pustaka Pelajar. 
Hasan, Z. (2017). Pelaksanaan Rehabilitasi Pecandu Narkoba Melalui Media Terapi Musik Sebagai Bentuk Implementasi Pasal 54 Undang-Undang Nomor 35 Tahun 2009 Tentang Narkotika di Lembaga Pemasyarakatan Kelas I Way Huwi Provinsi Lampung. Keadilan Progresif, 8(2). http://jurnal.ubl.ac.id/index.php/KP/article/view/941

Hasan, Z., \& Firmansyah, D. (2020). Disparitas Penerapan Pidana terhadap Pelaku Penyalahgunaan Narkotika. Pranata Hukum, 15(2), 221-237. https://doi.org/10.36448/PRANATAHUKUM.V15I2.232

Hidayatun, S., \& Widowaty, Y. (2020). Konsep Rehabilitasi bagi Pengguna Narkotika yang Berkeadilan. Jurnal Penegakan Hukum Dan Keadilan, 1(2). https://doi.org/10.18196/JPHK.1209

Hikmawati, P. (2016). Analisis terhadap Sanksi Pidana bagi Pengguna Narkotika. Negara Hukum: Membangun Hukum Untuk Keadilan Dan Kesejahteraan, 2(2), 329-350. https://doi.org/10.22212/JNH.V2I2.220

Jainah, Z. O. (2020). Kewajiban Rehabilitasi Medis Korban Penyalahgunan Narkotika. KEADILAN PROGRESIF, 11(1). http://jurnal.ubl.ac.id/index.php/KP/article/view/1498

Jamal, I. M. (2020). The Early Preventive Effort of Narcotic Abuse at Senior High School (SMA) in Aceh Besar and Sabang (A Study According to Islamic Law). Samarah: Jurnal Hukum Keluarga Dan Hukum Islam, 4(1), 282-312. https://doi.org/10.22373/SJHK.V4I1.6764

Joseph Solomon, O., \& Nwankwoala, R. (2014). The Role of Restorative Justice in Complementing the Justice System and Restoring Community Values in Nigeria. Asian Journal of Humanities and Social Sciences (AJHSS), 2(3). www.ajhss.org126

Kokong, A. S. (2012). Pidana Penjara Seumur Hidup dalam Sistem Pemidanaan. Lex Crimen, 1(2). https://ejournal.unsrat.ac.id/index.php/lexcrimen/article/view/414

Kupas Tuntas. (2019, October 28). Baru Sebulan Bebas Dari Penjara, Residivis Pengedar Narkoba Kembali Ditangkap Polisi. Kupastuntas.co. https://www.kupastuntas.co/2019/10/28/baru-sebulan-bebas-dari-penjararesidivis-pengedar-narkoba-kembali-ditangkap-polisi

Napitupulu, E. A. T., \& Rahmawati, M. (2019). Tindak Pidana Narkotika dalam Rancangan Kitab Undang-undang Hukum Pidana: Jerat Penjara untuk Korban Narkotika Penyusun.

Priyatno, D. (2009). Sistem Pelaksanaan Pidana Penjara di Indonesia. Refika Aditama. Roy, G. (2014). Is Capital Punishment Acceptable? International Journal of Humanities and Social Science, 4(2), 95-98.

Senjaya, O., Iman, C. H., \& Marlina, R. (2021). Sosialisasi Peran Badan Narkotika Nasional Kabupaten Karawang Serta Masyarakat Dalam Upaya Pencegahan Penyalahgunaan Narkotika di Masa Pandemi Covid-19. Dinamisia: Jurnal Pengabdian Kepada Masyarakat, 5(3), 741-747. https://doi.org/10.31849/DINAMISIA.V5I3.5882

Sugiyono. (2011). Metode Penelitian Kuantitatif Kualitatif dan $R \&$ D. Alfabeta. 
Triyanto, M., \& Triyanto, M. A. (2020). Implementasi Pola Pembinaan bagi Narapidana Narkoba. JUSTITIA: Jurnal Ilmu Hukum Dan Humaniora, 7(2), 317-327. https://doi.org/10.31604/justitia.v7i2.317-327

Yuherawan, D. S. B., \& Rosdiana, B. S. (2020). Ketidaktepatan Penjatuhan Pidana Penjara terhadap Penyalahguna Narkotika. Jurnal Ius Constituendum, 5(2), 177195. https://doi.org/10.26623/JIC.V5I2.2207 